\title{
PEMANFAATAN FILM SEBAGAI MEDIA PEMBELAJARAN \\ SEJARAH KEBUDAYAAN ISLAM (SKI) \\ DI MTSN MODEL PADANG
}

\author{
Zulvia Trinova, Nini \\ Email : nini.ihsan@yahoo.co.id \\ Fakultas Tarbiyah dan Keguruan UIN Imam Bonjol Padang
}

\begin{abstract}
Abstrak
Guru SKI pada umumnya cenderung menggunakan metode konvensional dengan hanya menggunakan media sederhana seperti papan tulis, media cetak seperti buku. Namun, guru yang mengajar Sejarah Kebudayaan Islam (yang selanjutnya disingkat dengan SKI) di MTsN Model Padang menggunakan media film dalam mengajar sehingga peserta didik termotivasi dalam belajar dan mudah memahami dan menguasai pelajaran. Penelitian ini bertujuan untuk mendeskripsikan teknik pemanfaatan film oleh guru sebagai media pembelajaran SKI, kesesuaian antara media film dengan materi pelajaran, respon peserta didik terhadap pemanfaatan film sebagai media pembelajaran SKI. Jenis penelitian yang digunakan adalah Field Research dan metode penelitian yang digunakan adalah metode deskiptif kualitatif. Teknik dan alat pengumpulan data menggunakan observasi, wawancara, dan dokumentasi. Pengolahan data dilakukan dengan teknik analisais deskriptif kualitatif. Kemudian membandingkan, mengecek keabsahan data, dan data dideskripsikan. Hasil penelitian di lapangan adalah: (1) Teknik pemanfaatan film oleh guru dalam pembelajaran SKI di MTsN Model Padang sudah baik. Guru SKI telah menguasai langkah-langkah penggunaan media film dan telah menggunakan strategi yang tepat dalam pembelajaran. (2) Media film dalam pembelajaran SKI di MTsN Model Padang hanya dapat digunakan pada SK dan KD tertentu saja. Media film digunakan hanya untuk menjelaskan materi tentang perjalanan dakwah Rasulullah di Mekah dan Madinah. (3) Respon peserta didik terhadap pemanfaatan film sebagai media pembelajaran SKI di MTsN Model Padang sangat baik. Penggunaan media film dalam pembelajaran SKI memberikan kesan positif bagi peserta didik dan mereka termotivasi dalam belajar karena menguasai materi yang disampaikan.
\end{abstract}

Kata Kunci: Pemanfaatan Media Pembelajaran, Media Film, Sejarah Kebudayaan Islam (SKI), Respon Peserta Didik, MTsN

\section{Pendahuluan}

Pendidikan Agama Islam di Madrasah Tsanawiyah terdiri atas empat mata pelajaran, yaitu: Al-Qur'an-Hadis, Akidah-Akhlak, Fikih, dan Sejarah Kebudayaan Islam (SKI). Masingmasing mata pelajaran tersebut pada dasarnya saling terkait, isi mengisi dan melengkapi.

SKI merupakan salah satu mata pelajaran yang sangat penting dalam pendidikan agama Islam karena dengan mempelajari SKI bisa mengetahui perkembangan perjalanan hidup muslim 
dari masa ke masa dalam usaha bersyariah (beribadah dan bermuamalah) dan berakhlak serta dalam mengembangkan sistem kehidupannya yang dilandasi oleh akidah (Permenag 2008, h. 48).

SKI di MTs merupakan salah satu mata pelajaran yang menelaah tentang asal-usul, perkembangan, peranan kebudayaan/peradaban Islam dan para tokoh yang berprestasi dalam sejarah Islam di masa lampau, mulai dari perkembangan masyarakat Islam pada masa Nabi Muhammad SAW dan Khulafaurrasyidin, Bani ummayah, Abbasiyah, Ayyubiyah sampai perkembangan Islam di Indonesia. Secara substansial, mata pelajaran SKI memiliki kontribusi dalam memberikan motivasi kepada peserta didik untuk mengenal, memahami, menghayati SKI, yang mengandung nilai-nilai kearifan yang dapat digunakan untuk melatih kecerdasan, membentuk sikap, watak, dan kepribadian peserta didik (Permenag 2008, h. 51).

Mata pelajaran SKI di MTs bertujuan agar peserta didik memiliki kemampuankemampuan sebagai berikut:

a. Membangun kesadaran peserta didik tentang pentingnya mempelajari landasan ajaran, nilai-nilai dan norma-norma Islam yang telah dibangun oleh Rasulullah saw dalam rangka mengembangkan kebudayaan dan peradaban Islam.

b. Membangun kesadaran peserta didik tentang pentingnya waktu dan tempat yang merupakan sebuah proses dari masa lampau, masa kini, dan masa depan.

c. Melatih daya kritis peserta didik untuk memahami fakta sejarah secara benar dengan didasarkan pada pendekatan ilmiah.

d. Menumbuhkan apresiasi dan penghargaan peserta didik terhadap peninggalan sejarah Islam sebagai bukti peradaban umat Islam di masa lampau.

e. Mengembangkan kemampuan peserta didik dalam mengambil ibrah dari peristiwa-peristiwa bersejarah (Islam), meneladani tokoh-tokoh berprestasi, dan mengaitkannya dengan fenomena sosial, budaya, politik, ekonomi, iptek dan seni, dan lain-lain untuk mengembangkan kebudayaan dan peradaban Islam (Permenag 2008, h. 51-52).

Dalam suatu proses belajar mengajar, dua unsur yang amat penting adalah metode mengajar dan media pengajaran. Kedua aspek ini saling berkaitan. Pemilihan satu metode pengajaran tertentu akan mempengaruhi jenis media pengajaran yang sesuai, meskipun masih ada berbagai aspek lain yang harus diperhatikan dalam memilih media, antara lain tujuan pengajaran, jenis tugas dan respons yang diharapkan peserta didik kuasai setelah pengajaran 
berlangsung, dan konteks pembelajaran termasuk karakteristik peserta didik (Azhar Arsyad, 2003: h. 15).

Salah satu fungsi utama media adalah sebagai alat bantu mengajar yang turut mempengaruhi iklim, kondisi, dan lingkungan belajar yang ditata dan diciptakan oleh guru. Penggunaan media pengajaran pada tahap orientasi pembelajaran akan sangat membantu keefektifan pembelajaran dan penyampaian pesan dan isi materi pada saat itu. Di samping membangkitkan motivasi dan minat peserta didik, media juga dapat membantu mereka meningkatkan pemahaman, menyajikan data dengan menarik dan terpercaya, memudahkan penafsiran data, dan memadatkan informasi.

Pendidik sudah seharusnya menggunakan media yang tepat dalam proses pembelajaran. Hal ini dikarenakan penggunaan media yang tepat akan mencapai tujuan pengajaran yang optimal serta dapat meningkatkan minat dan hasil belajar peserta didik khususnya pelajaran SKI. Salah satu dari media yang tepat adalah media film.

Media film dapat menggambarkan suatu obyek yang bergerak bersama-sama dengan suara alamiah atau suara yang sesuai. Kemampuan melukiskan gambar hidup dan suara memberinya daya tarik tersendiri. Secara umum film digunakan untuk tujuan-tujuan hiburan, dokumentasi dan pendidikan (Azhar Arsyad, 2003: h. 48).

Media film merupakan sebuah media pembelajaran yang sangat menarik karena mampu mengungkapkan keindahan dan fakta bergerak dengan efek suara, gambar dan gerak, film juga dapat diputar berulang-ulang sesuai dengan kebutuhan. Selain itu, beberapa keunggulan film sebagai media pembelajaran adalah:

a. keterampilan membaca atau menguasai penguasaan bahasa yang kurang, bisa diatasi dengan menggunakan film sangat tepat untuk menerangkan suatu proses

b. dapat menyajikan teori ataupun praktek dari yang bersifat umum ke yang bersifat khusus ataupun sebaliknya

c. film dapat mendatangkan seorang yang ahli dan memperdengarkan suaranya di depan kelas

d. film dapat lebih realistis, hal-hal yang abstrak dapat terlihat menjadi lebih jelas

e. film juga dapat merangsang motivasi kegiatan peserta didik (Dadang Supriatna, 2009: h. 12).

Dalam film peserta didik juga dapat melihat dan mendengar pengalaman-pengalaman yang direkam, fiksi, bayangan, drama, cerita-cerita rekreasi dan episode masa lampau, yang 
merupakan kombinasi antara gerakan, kata-kata, musik dan warna (Oemar Hamalik, ,1989, h. 84).

MTsN Model Padang (Sejak tahun 2018 berubah nama menjadi MTsN 6 Padang) merupakan salah satu madrasah tsanawiyah yang berada di kota Padang. Tepatnya di daerah Gunung Pangilun. Letak madrasah ini berada di kawasan pendidikan yakninya berhadaphadapan dengan STKIP PGRI dan bersebelahan dengan MIN Model, RA dan MAN 2 Padang. Sesuai dengan namanya, MTsN ini telah mengukir banyak prestasi di berbagai bidang, baik akademik maupun non akademik, mulai dari tingkat kota sampai tingkat Nasional. Begitu juga dalam hal proses pengajaran, madrasah ini menerapkan sistem pengajaran yang bagus. Salah satu diantaranya adalah dalam pembelajaran SKI.

Di tengah kebiasaan guru SKI pada umumnya yang cenderung menggunakan metode ceramah dengan hanya menggunakan media sederhana seperti papan tulis dan lain-lain, guru yang mengajar SKI kelas VII di MTsN Model Padang menggunakan media film dalam mengajar sehingga peserta didik termotivasi dalam belajar dan mudah memahami dan menguasai pelajaran.

\section{Metodologi}

\section{Media dalam Pembelajaran}

Kata media berasal dari bahasa Latin "medius" dan merupakan bentuk jamak dari kata "medium" yang secara harfiah berarti tengah, perantara atau pengantar. Dalam bahasa arab media dikenal dengan istilah "wasail" yang berarti perantara atau pengantar pesan dari pengirim kepada penerima pesan (Azhar Arsyad, 2008: h. 3).

Asosiasi Teknologi dan Komunikasi Pendidikan (Association of Education and Communication Technology/AECT) di Amerika, membatasi media sebagai segala bentuk dan saluran yang digunakan orang untuk menyalurkan pesan/informasi. Asosiasi Pendidikan Nasional (National Education Assosiation/NEA) memiliki pengertian yang berbeda. Media adalah bentuk-bentuk komunikasi baik tercetak maupun audiovisual serta peralatannya. Media hendaknya dapat dimanipulasi, dapat dilihat, di dengar dan dibaca. Apapun batasan yang diberikan, ada persamaan di antara batasan tersebut yaitu bahwa media adalah segala sesuatu yang dapat digunakan untuk menyalurkan pesan dari pengirim ke penerima sehingga dapat 
merangsang pikiran, perasaan dan perhatian dan minat serta perhatian peserta didik sedemikian rupa sehingga terjadi (Arief S. Sadarman, dkk, 2007: h. 6-7).

Menurut R. Ibrahim, media pembelajaran diartikan sebagai segala sesuatu yang dapat digunakan untuk menyalurkan pesan atau isi pelajaran, merangsang pikiran, perasaan, perhatian dan kemampuan peserta didik, sehingga dapat mendorong proses belajar-mengajar (R. Ibrahim, 2003: h. 112).

Dalam belajar mengajar, sering pula pemakaian kata media pembelajaran digantikan dengan istilah-istilah seperti alat pandang dengar, bahan pengajaran (instructionala material), komunikasi pandang dengar (audio-visual communication), pendidikan alat peraga pandang (visual education), teknologi pendidikan (educational technology), alat peraga dan media penjelas (Azhar Arsyad, 2008: h. 6). Jadi yang dimaksud dengan media pembelajaran adalah alat bantu yang dapat digunakan dalam rangka lebih mengefektifkan komunikasi dan interaksi antara guru dan peserta didik dalam proses pembelajaran di sekolah.

Ada beberapa klasifikasi media pembelajaran menurut para ahli:

1. Menurut Rudy Bretz

Bretz mengidentifikasi ciri utama dari media menjadi tiga unsur pokok, yaitu suara, visual dan gerak. Visual dibedakan menjadi tiga yaitu gambar, garis (line graphic), dan simbol yang merupakan suatu kontinum dari bentuk yang dapat ditangkap dengan indra penglihatan.

\section{Menurut Briggs}

Pendapat briggs lebih mengarah pada karakteristik menurut stimulus atau rangsangan yang dapat ditimbulkan dari media sendiri, yaitu kesesuaian rangsangan tersebut dengan karakteristik peserta didik, tugas pembelajaran, bahan dan transmisinya. Briggs mengidentifikasi 13 macam media yang dipergunakan dalam proses belajar mengajar, yaitu objek, model, suara langsung, rekaman audio, media cetak, pembelajaran terprogram, papan tulis, media transparansi, film rangkai, film bingkai, film, televisi, dan gambar (Martinis Yamin, 2008: h. $183)$.

Ada beberapa jenis media pembelajaran yang biasa digunakan:

1. Media grafis seperti gambar, foto, grafik, bagan atau diagram, poster, kartun, komik dan lain-lain. Media grafis sering disebut media dua dimensi, yakni media yang mempunyai ukuran panjang dan lebar. 
2. Media tiga dimensi yaitu dalam bentuk model seperti model padat ( solid model), model penampang, model susun, model kerja, mock up, diorama dan lain-lain.

3. Media proyeksi seperti slide, filmsrip, film, penggunaan OHP dan lain-lain

4. Penggunaan lingkungan sebagai media pendidikan (Harjanto, 2006: h. 237).

Pemilihan media pembelajaran dapat dilihat pada beberapa aspek berikut ini:

Ditinjau dari kesiapan pengadaannya, media dikelompokkan dalam dua jenis, yaitu media jadi karena sudah menjadi komoditi perdagangan dan terdapat di pasaran luas dalam keadaan siap pakai (media by utilization) dan media rancangan karena perlu dirancang dan dipersiapkan secara khusus untuk maksud dan tujuan pembelajaran tertentu (media by design). Masing-masing media ini memiliki kelebihan dan keterbatasan. Kelebihan dari media jadi adalah hemat dalam waktu, tenaga dan biaya untuk mengadakannya. Sebaliknya mempersiapkan media yang dirancang secara khusus untuk memenuhi kebutuhan tertentu akan memeras banyak waktu, tenaga maupun biaya karena untuk mendapatkan keandalan dan kesahihannya diperlukan serangkaian kegiatan validasi prototipnya. Kekurangan dari media jadi adalah kecilnya kemungkinan untuk mendapatkan media jadi yang dapat sepenuhnya sesuai dengan tujuan atau kebutuhan pembelajaran setempat. Mungkin, faktor waktu, tenaga dan biaya ini dikaitkan dengan laju perkembangan ilmu pengetahuan dan teknologi modern yang menyebabkan banyak negara berkembang memilih media jadi baik untuk diangkat secara utuh dengan modifikasi seperlunya, maupun diadaptasikan dengan keadaan setempat (Arief S. Sadirman, dkk, 2007: h. 83-84).

Dasar pertimbangan untuk memilih suatu media sangatlah sederhana, yaitu dapat memenuhi kebutuhan atau mencapai tujuan yang diinginkan atau tidak. Mc Connel (1974) mengatakan bila media itu sesuai maka pakailah, "If the Medium Fits, Use it!" .

Kriteria pemilihan media harus dikembangkan sesuai dengan tujuan yang ini dicapai, kondisi dan keterbatasan yang ada dengan mengingat kemampuan dan sifat-sifat khasnya (karakteristik) media yang bersangkutan. Hakikat dari pemilihan media pada akhirnya adalah keputusan untuk memakai, tidak memakai, atau mengadaptasi media yang bersangkutan (Arief S. Sadirman, dkk, 2007: h. 85-86).

Dalam penggunaan media, guru harus mengikuti langkah-langkah tertentu, dengan perencanaan yang sistematik. Ada enam langkah yang bisa ditempuh guru pada waktu ia mengajar dengan mempergunakan media. Langkah-langkah itu adalah:

1. Merumuskan tujuan pengajaran dengan memanfaatkan media 
2. Persiapan guru. Pada fase ini guru memilih dan menetapkan media mana yang akan dimanfaatkan guna mencapai tujuan. Dalam hal ini prinsip pemilihan dan dasar pertimbangannya patut diperhatikan.

3. Persiapan kelas. Pada fase ini peserta didik atau kelas harus mempunyai persiapan, sebelum mereka menerima pelajaran dengan menggunakan media. Guru harus dapat memotivasi agar dapat menilai, mengantisipasi, menghayati pembelajaran dengan menggunakan media pembelajaran.

4. Langkah penyajian pelajaran dan pemanfaatan media. Pada fase ini penyajian bahan pelajaran dengan memanfaatkan media pengajaran. Media diperbantukan oleh guru untuk membantu tugasnya menjelaskan bahan pengajaran. Media dikembangkan penggunaannya untuk keefektifan dan efisiensi pencapaian tujuan.

5. Langkah kegiatan belajar peserta didik. Pada fase ini peserta didik belajar dengan memanfaatkan media pengajaran. Pemanfaatan media disini bisa peserta didik sendiri yang mempraktekkannya ataupun guru langsung memanfaatkannya, baik di kelas atau di luar kelas.

6. Langkah evaluasi pengajaran. Pada langkah ini kegiatan belajar dievaluasi, sampai sejauh mana tujuan pembelajaran tercapai, yang sekaligus dapat dinilai sejauhmana pengaruh media sebagai alat bantu dapat menunjang keberhasilan proses belajar peserta didik. Hasil evaluasi dapat dijadikan dasar atau bahan bagi proses belajar berikutnya (Syaiful Bahri Djamarah, dkk.: h. 136).

Manfaat praktis dari penggunaan media pembelajaran di dalam proses belajar mengajar sebagai berikut:

1. Media pengajaran dapat memperjelas penyampaian pesan dan informasi sehingga dapat memperlancar dan meningkatkan proses dan hasil belajar

2. Media pembelajaran dapat meningkatkan dan mengarahkan perhatian anak sehingga dapat menimbulkan motivasi belajar, interaksi yang lebih langsung antara peserta didik dan lingkungannya, dan kemungkinan peserta didik untuk belajar sendiri-sendiri sesuai dengan kemampuan dan minatnya

3. Media pembelajaran dapat mengatasi keterbatasn indera, ruang dan waktu;

a. Objek atau benda yang terlalu besar untuk ditampilkan langsung diruang kelas dapat diganti dengan gambar foto, slide, realita, film, radio atau model 
b. Objek atau benda yang terlalu kecil yang tidak tampak oleh indera dapat disajikan dengan bantuan mikroskop, film, slide atau gambar

c. Kejadian langka yang terjadi di masa lalu atau sekali terjadi dalam puluhan tahun dapat ditampilkan melalui rekaman video, film, foto, slide di samping secara verbal

d. Objek atau proses yang amat rumit seperti peredaran darah dapat ditampilkan secara konkret melalui film, gambar, slide, atau simulasi komputer

e. Kejadian atau percobaan yang dapat membahayakan dapat disimulasikan dengan media seperti komputer, film dan video

f. Peristiwa alam seperti terjadinya letusan gunung berapi atau proses yang dalam kenyataannya memakan waktu lama seperti proses kepompong menjadi kupu-kupu dapat disajikan dengan teknik-teknik rekaman seperti time-lapse untuk film, video, slide atau simulasi komputer.

4. Media pembelajaran dapat memberikan kesamaan pengalaman kepada peserta didik tentang peristiwa-peristiwa di lingkungan mereka, serta memungkinkan terjadinya interaksi langsung dengan guru, masyarakat dan lingkungannya misalnya melalui karyawisata, kunjungankunjungan ke museum atau kebun binatang (Azhar Arsyad, 2008: h. 21-27).

\section{Pemanfaatan Film sebagai Media Pembelajaran SKI}

1. Film dan Sejarah Pemanfaatan Film sebagai Media Pembelajaran

Film atau gambar hidup sudah lama dikenal orang. Dalam perkembangannya memakan waktu yang cukup lama untuk perbaikan dan penyempurnaannya. Kehadiran film di tengahtengah masyarakat sejak dahulu sampai sekarang menimbulkan berbagai tanggapan. Ada yang pro, dengan alasan bahwa film dapat menjadi penyebaran nilai-nilai kemanusiaan yang tinggi; tetapi dipihak yang kontra menganggap bahwa film dapat menjadi sumber bermacam-macam kejahatan. Tentunya masing-masing pihak tadi memiliki alasan, karena memang film mengandung unsur positif dan negatif. Menurut Margija Mangunhardjana (1976:7), film bisa memperkaya pengalaman hidup, tetapi juga bisa menutup segi-segi kehidupan yang lebih mendalam. Film bisa menyajikan hal-hal yang baru dan berguna, tetapi juga bisa membingungkan orang, sebab hal-hal yang baru itu tidak bisa dipecahkannya sendiri. Melalui film orang bisa mempelajari tata kehidupan serta perilaku yang baru, tetapi film juga bisa menjadi alat peniruan yang salah. 
Pada tahap permulaan film bersuara digunakan sebagai media pembelajaran, banyak pendidik yang melawan ide tersebut. Beberapa administrator pendidikan juga melawan adanya penggunaan film bersuara di sekolah, karena menurut mereka, hasil teknologi yang baru itu (film bersuara) akan membuat film bisu yang selama ini digunakan menjadi ketinggalan zaman/kuno.

\section{Sifat-sifat Film}

Sifat dasar dari suatu gambar yang bergerak ialah kemampuannya untuk memanipulasi ruang dan waktu, tidak hanya sekedar memperoleh sesuatu yang mengandung unsur kreatif dan dramatis, tetapi yang penting adalah penerapannya dalam dunia pendidikan, khususnya dalam proses pembelajaran.

a. Manipulasi Ruang

Film dapat melihat fenomena/peristiwa-peristiwa di mikrokosmos maupun makrokosmos, pada jangkauan yang dekat ataupun yang sangat jauh jaraknya.

b. Peralihan Waktu

Film dapat melampaui ruang. Contoh, film yang memperlihatkan perang saudara di suatu negara hanya dalam waktu beberapa jam saja.

c. Penekanan waktu (Time lapse)

Film dapat menekankan waktu yang digunakan untuk terjadinya suatu peristiwa. Contoh, film yang memperlihatkan peristiwa mekarnya suatu kembang. Proses suatu kepompong yang berubah menjadi kupu-kupu terlalu lama untuk diadakan observasi oleh para peserta didik.

d. Perluasan waktu (slow motion)

Dengan mengabadikan/merekam peristiwa itu pada kecepatan tinggi, kemudian diproyeksikan pada kecepatan normal maka dapat mengamati apa yang terjadi. Contoh, dalam kegiatan olahraga, dapat menganalisis gerakan dari para atlit yang melompat, lari atau berenang, setelah film itu diputar kembali dengan menggunakan teknik slow motion.

e. Menampakkan hal yang tak tampak

Film dapat mengamati kerjanya suatu obyek yang secara normal tidak dapat dilihat. Contoh dengan teknik sinematografi yang menggunakan sinar $\mathrm{X}$ dapat melihat bagaimana kerja katup jantung waktu jantung berkontraksi (berdenyut); atau bagaimana kerjanya tulang iga ketika orang bernafas.

f. Menahan gerakan 
Film memisahkan bagian perbagian dari suatu peristiwa, agar dapat dipelajari secara seksama. Misalnya pembuat film dapat memilih suatu gambar dari suatu urutan gerakan kemudian melihat gambar itu berulang-ulang (beberapa kali), sehingga waktu diproyeksikan maka nampak tetap di layar (John D. Latuheru, 1988: 93-95).

3. Manfaat film dalam proses pembelajaran

Manfaat film dalam proses pembelajaran:

a. Sifat-sifat yang nyata pada film dalam proses pembelajaran adalah kemampuannya untuk memperlihatkan gerakan-gerakan. Hal ini membuat film lebih menguntungkan dibandingkan dengan media lain.

b. Film dapat menyajikan suatu proses dengan lebih tepat guna (efektif) dibanding dengan media lain.

c. Film memungkinkan adanya pengamatan yang baik terhadap suatu keadaan/peristiwa yang berbahaya bila dilihat secara langsung, dapat dilihat/diamati secara baik dan meyakinkan.

d. Kemampuan film untuk mendramatisasikan peristiwa-peristiwa dan situasi yang membuatnya cocok bagi PBM dalam bidang ilmu-ilmu sosial dan masalah-masalah kemanusiaan.

e. Menurut hasil penelitian terbukti bahwa film sangat berguna untuk mengajar keterampilan, kerena kemungkinan adanya pengulangan sehingga suatu keterampilan bisa dipelajari secara berulang-ulang juga.

f. Memiliki dampak emosional yang tinggi/besar, film sangat cocok untuk mengajarkan masalah yang menyangkut domain afektif.

g. Suatu episode film dapat digunakan secara tepat guna dalam situasi pembelajaran yang menekankan pada proses pemecahan masalah.

h. $\quad$ Film yang memperlihatkan suatu kebudayaan asing yang mengandung nilai-nilai positif.

i. Suatu PBM yang berlangsung dengan menggunakan film sebagi media, akan mempunyai pengaruh psikologis yang lebih menguntungkan bagi para peserta didik, dibanding dengan media lain

j. Kemampuan film dalam hal mengadakan "close-up", "timelapse" dan lain-lain karakteristik yang dimilikinya sangat menarik perhatian peserta didik untuk mengamati secara 517 | Seminar Nasional Sejarah ke 4 Jurusan Pendidikan Sejarah Universitas Negeri Padang 
teliti suatu bagian tertentu dari materi pembelajaran. Hal seperti ini tidak dimiliki oleh media lain.

k. Film adalah media pembelajaran yang cocok untuk kelompok yang heterogen, kelompok kecil maupun besar dan individual (John D. Latuheru, 1988: 95-96).

4. Pemanfaatan film sebagai media pembelajaran sejarah

Mempelajari sejarah lewat film lebih mengasyikkan daripada sekedar membacanya melalui buku. Karakter film sebagai media audio visual membuat pembelajaran terasa lebih menarik. Film bertemakan sejarah juga secara langsung dapat membaca suatu interpretasi sejarah berikut fakta-fakta sosial yang terkandung di dalamnya. Dengan kata lain, menikmati suatu film bertemakan sejarah serasa membaca suatu analisa peristiwa sejarah yang komprehensif daripada sekedar menghafal nama-nama tokoh sejarah serta peristiwa-peristiwa penting yang melatarbelakanginya. Hal ini dapat mempermudah pemahaman sejarah serta membuatnya tidak membosankan. Tentu saja penggunaan film sebagai media pembelajaran sejarah mesti didasari oleh suatu riset mengenai peristiwa sejarah atau tokoh yang akan difilmkan berikut riset-riset lain misalnya tentang arsitektur dan tata kota suatu lokasi yang akan menjadi suatu setting film sejarah (Endiarto wijaya,Film Indonesia Pembelajaran Sejarah(http://sosbud.kompasiana.com/2009/12/19/film-indonesia-dan-pembelajaran-sejarah).

\section{Sejarah Kebudayaan Islam (SKI)}

SKI merupakan salah satu mata pelajaran yang sangat penting dalam pendidikan agama Islam karena dengan mempelajari SKI bisa mengetahui perkembangan perjalanan hidup manusia muslim dari masa ke masa dalam usaha bersyariah (beribadah dan bermuamalah) dan berakhlak serta dalam mengembangkan sistem kehidupannya yang dilandasi oleh akidah (Permenag 2008: h. 48).

SKI di MTs merupakan salah satu mata pelajaran yang menelaah tentang asal-usul, perkembangan, peranan kebudayaan/peradaban Islam dan para tokoh yang berprestasi dalam sejarah Islam di masa lampau, mulai dari perkembangan masyarakat Islam pada masa Nabi Muhammad SAW dan Khulafaurrasyidin, Bani ummayah, Abbasiyah, Ayyubiyah sampai perkembangan Islam di Indonesia. Secara substansial, mata pelajaran SKI memiliki kontribusi dalam memberikan motivasi kepada peserta didik untuk mengenal, memahami, menghayati SKI, yang mengandung nilai-nilai kearifan yang dapat digunakan untuk melatih kecerdasan, membentuk sikap, watak, dan kepribadian peserta didik (Permenag 2008: h. 51). 
Secara singkat apa yang telah dilihat pada sebuah film hendaknya dapat memberikan hasil yang nyata bagi peserta didik. Dalam menilai baik atau tidaknya sebuah film, Oemar Hamalik (1985: 109-110) mengemukakan bahwa film yang baik memiliki ciri-ciri sebagai berikut:
a. Dapat menarik minat anak
b. Benar dan autentik
c. Up to date
d. Sesuai dengan tingkat kematangan peserta didik
e. Perbendaharaan bahasa yang dipergunakan secara benar
f. Kesatuan dan sequence-nya cukup teratur
g. Teknis yang dipergunakan cukup memenuhi persyaratan dan cukup memuaskan (Basyiruddin Usman dan Asnawir, 2002: h. 96-98).

Penelitian ini adalah penelitian lapangan (Field Research) yang bersifat deskriptif. Penelitian deskriptif merupakan metode penelitian yang menggambarkan secara sistematis fakta dan karakteristik objek atau subjek yang diteliti secara tepat atau sebagaimana adanya (Sukardi, 2004: h. 157). Metode yang digunakan dalam penelitian ini adalah metode kualitatif. Metode kualitatif dapat diartikan sebagai prosedur pemecahan masalah yang diselidiki dengan menggambarkan objek penelitian berdasarkan fakta-fakta yang tampak.

Untuk mendapatkan informasi tentang pemanfaatan film sebagai media pembelajaran SKI di MTsN Model Padang, maka penulis perlu menetapkan sumber data primer (Guru SKI sebanyak satu orang) dan sekunder (peserta didik dan Kepala MTsN Model Padang).

Teknik pengumpulan data adalah observasi dengan melihat secara langsung pemanfaatan film sebagai media pembelajaran SKI ini yang dilakukan selama proses pembelajaran di kelas; wawancara secara langsung dengan guru SKI, kepala sekolah dan peserta didik tentang pemanfaatan film sebagai media pembelajaran SKI dan apa yang dirasakan oleh peserta didik setelah pelaksanaannya; dokumentasi melihat perencanaan yang telah dibuat sebelum pembelajaran dan daftar penilaian peserta didik. Teknik pengolahan data meliputi reduksi data, penyajian data, dan kesimpulan terkait dengan pemanfaatan film sebagai media pembelajaran SKI di MTsN Model Padang. Data yang telah diolah, dianalisis dengan menggunakan model analisis yang dikembangkan oleh Miles dan Huberman. Data yang terkumpul lalu diolah, diseleksi atas dasar reliabilitas dan validitasnya. 


\section{Hasil dan Pembahasan}

\section{Teknik Pemanfaatan Film oleh Guru sebagai Media Pembelajaran SKI di}

\section{MTsN Model Padang}

Perkembangan ilmu pengetahuan dan teknologi telah membawa pengaruh terhadap perkembangan dunia pendidikan. Untuk itu tenaga pengajar dituntut memiliki kemampuan dan kecakapan yang lebih serta mampu memanfaatkan media yang menggunakan peralatan teknologi modern yang relevan dengan tuntutan masyarakat dan perkembangan zaman.

Berdasarkan hasil observasi di MTsN Model Padang, secara umum guru-guru bidang PAI telah menggunakan media pembelajaran. Mulai dari media sederhana sampai media yang menggunakan peralatan elektronik seperti film, powerpoint, dan lain-lain. Salah seorang di antara guru yang menggunakan media itu adalah guru yang mengajar mata pelajaran SKI yang bernama Masnidar, beliau memanfaatkan film sebagai media pembelajaran SKI.

Berdasarkan wawancara dengan Masnidar mengenai media pembelajaran yang digunakan dalam pembelajaran SKI beliau mengatakan bahwa beliau dalam mengajar sangat senang menggunakan media, media yang digunakan itu disesuaikan dengan materi pelajaran. Materi pelajaran SKI kelas VII tentang perjalanan dakwah rasulullah di Mekah dan Madinah. Maka saya gunakan film the message sebagai media pembelajaran”.

Terkait tentang cara mendapatkan atau memperoleh film tersebut, beliau mengatakan bahwa beliau mendownload film tersebut dari Internet. Film the message yang berdurasi 2 jam itu beliau download dengan menghabiskan waktu sekitar 2 hari dengan bantuan anak beliau

Lebih lanjut beliau mengatakan bahwa media film yang digunakan memudahkan peserta didik memahami dan mengingat sejarah islam terutama sejarah dakwah nabi. Selama ini, tanpa menggunakan media film peserta didik sangat sulit memahami dan mengingat sejarah sehingga ketika peserta didik ditanya lagi tentang materi itu pada minggu berikutnya, tidak beberapa dari peserta didik yang ingat. Di samping itu, peserta didik kurang bersemangat belajar SKI kalau tidak didukung oleh penggunaan media yang baik.

Berdasarkan wawancara penulis dengan kepala madrasah, beliau mengatakan bahwa guru SKI telah memiliki kreativitas yang bagus dalam memanfaatkan film sebagai media pembelajaran. Hal ini sekaligus menjadi modal bagi guru SKI untuk menepis anggapan peserta 
didik bahwa pembelajaran SKI membosankan karena biasanya SKI cenderung metodenya ceramah dan medianya papantulis dan buku saja.

Hasil wawancara di atas menjelaskan bahwa dalam pembelajaran SKI sangat dituntut kreativitas guru dalam memilih memanfaatkan media pembelajaran yang cocok dan media film sangat cocok digunakan dalam pembelajaran SKI, yang dapat memudahkan peserta didik memahami dan mengingat materi pelajaran serta membuat anak semangat belajar.

Dalam penggunaan media film ada beberapa langkah yang harus ditempuh oleh guru, yaitu:

a. Langkah persiapan guru

Pada langkah ini, guru mempersiapkan unit pelajaran terlebih dahulu, kemudian memilih film yang tepat untuk mencapai tujuan yang diharapkan serta memperkirakan durasi film dengan waktu yang tersedia.

Berdasarkan wawancara penulis dengan kepala madrasah, beliau mengatakan bahwa dari segi perencanaan pembelajaran SKI dengan pemanfaatan media film sudah bagus, karena guru SKI memiliki inisiatif untuk bekerja sama dengan guru bidang studi lain dalam hal waktu dan beliau memberi kebebasan bagi guru untuk hal seperti itu, asalkan memang hal itulah yang terbaik dan tidak merugikan peserta didik dan guru dalam pembelajaran yang lain.

Berdasarkan wawancara penulis dengan guru SKI, bahwa dalam tahap persiapan ini beliau memperkirakan durasi film yang 2 jam diputarkan dalam 4 jam pelajaran, sehingga beliau menggabungkan 2 lokal sekaligus dalam sekali penayangan film. Untuk itu beliau bekerja sama dengan guru bidang studi lain untuk berganti jam pelajaran.

Menurut penulis, cara yang dilakukan guru SKI ini dalam persiapan, sudah baik dan efektif karena film dapat ditayangkan sekaligus dalam satu kali pertemuan sehingga anak bisa memahami materi dalam film secara keseluruhan. Di samping itu, penulis juga melihat salah satu kelebihan dari media film, bahwa media film lebih menarik bagi peserta didik dibandingkan dengan mendengar penjelasan guru saja, sehingga walaupun jumlah peserta didik melebihi jumlah normal satu kelas, keadaan kelas tetap kondusif.

\section{b. Mempersiapkan Kelas}

Berdasarkan wawancara penulis dengan guru SKI, beliau mengatakan bahwa sebelum film diputarkan, materi yang terkait dengan film telah dijelaskan terlebih dahulu pada pertemuan sebelumnya. Hal ini menurut penulis sudah tepat dan dapat memudahkan peserta didik 
memahami cerita dalam film, karena pada saat menonton film tersebut, peserta didik telah memiliki pengetahuan dasar terkait cerita dalam film.

Lebih lanjut guru SKI mengatakan pada saat peserta didik menonton film, beliau memberikan penjelasan-penjelasan singkat pada bagian-bagian yang sulit dipahami. Seperti nama tokoh, alur cerita dan tempat, sehingga keraguan-keraguan yang mungkin ada pada pemikiran peserta didik pada saat menonton film, akan hilang karena sudah dijelaskan oleh guru.

c. Langkah Penyajian

Berdasarkan hasil wawancara dengan guru SKI, pada saat beliau menayangkan film dalam pembelajaran SKI di kelas VII, beliau menggunakan ruangan multimedia. Untuk pemutaran film beliau menggunakan perlengkapan seperti laptop, proyektor, layar dan speaker.

Sebelum peserta didik masuk ruangan multimedia, guru SKI dengan bantuan guru yang profesional dalam pengoperasian peralatan elektonik, telah menyiapkan segala peralatan untuk pemutaran film. Maka pada saat peserta didik telah berada di ruangan multimedia dan telah diatur tempat duduknya, guru memberikan pengantar terkait dengan materi pelajaran yang akan disaksikan peserta didik dalam film. Setelah itu proyektor dinyalakan dan film diputarkan. Pada saat film diputar, dan ada adegan yang sulit dipahami peserta didik, maka guru memberikan penjelasan. Penayangan film berlangsung selama 120 menit dengan dua kali jeda, yaitu jeda setelah penayangan dakwah nabi periode mekah dan jeda setelah penayangan dakwah nabi periode madinah. Jeda tersebut dimanfaatkan sebagai sesi tanya jawab dari peserta didik ke guru ataupun sebaliknya.

Dari hasil wawancara penulis dengan peserta didik, penyajian tersebut bisa membuat peserta didik merasa nyaman, mudah mengerti, tidak bosan dan mampu menyampaikan kembali apa yang di apatkan dari film tersebut.

d. Aktivitas lanjutan

Berdasarkan wawancara penulis dengan guru SKI, setelah penayangan film berakhir guru meminta peserta didik untuk menyampaikan pelajaran-pelajaran yang bisa diambil dari film tersebut, postes berupa pertanyaan secara tertulis terkait dengan cerita film dan sebelum aktivitas pembelajaran ditutup, peserta didik diberi tugas untuk membuat kembali alur cerita sesuai dengan film yang telah ditonton di buku tugas.

Secara totalitas penulis melihat bahwa teknik pemanfaatan film oleh guru dalam pembelajaran SKI di kelas VII MTsN Model Padang sudah tepat. Mulai dari pemilihan media, 
cara memperoleh media, sampai kepada langkah-langkah penggunaannya. Dapat disimpulkan bahwa guru dalam menggunakan media film terutama dalam pembelajaran SKI, mesti menguasai teknik pemanfaatannya dan strategi tertentu sehingga media film dapat dipergunakan secara efektif.

\section{Kesesuaian antara media film dengan materi pelajaran di MTsN Model}

\section{Padang}

Film yang digunakan sebagai media pembelajaran SKI harus sesuai dengan materi pelajaran. Agar tidak terjadi kesalahpahaman pada saat menonton film.

Berdasarkan wawancara penulis dengan guru SKI tentang kesesuaian film dengan materi pelajaran, bahwa tidak semua materi SKI bisa mempergunakan media film, materi yang diajarkan dengan mempergunakan media film adalah tentang sejarah perjalanan dakwah rasulullah di Mekah dan Madinah. Guru SKI menjelaskan bahwa berdasarkan SK dan KD itu, beliau memilih film the message sebagai film yang dijadikan media pembelajaran SKI. Film ini dipilih karena isi dan adegan film sesuai dengan materi pelajaran SKI yang diajarkan. Setelah penulis mengamati secara langsung film yang diputarkan itu, film The Message memang cocok untuk dijadikan media pembelajaran SKI karena ada kesesuaian antara film dengan sejarah dari segi penayangan para tokoh, karakter tokoh, dan adegan.

Dari segi penayangan para tokoh dalam film, seperti nabi Muhammad dan Khulafaurrasyidin tidak diperlihatkan wujud tokohnya. Hal ini membuktikan bahwa film the Message sangat menjaga originalitas nabi Muhammad dan Khulafaurrasyidin. Berdasarkan hasil wawancara dan hasil pengamatan penulis, dapat disimpulkan bahwa film yang digunakan sebagai media pembelajaran SKI di MTsN Model Padang sesuai dengan materi pelajaran. Sehingga penulis merasa bahwa film juga bisa digunakan sebagai media pada materi SKI yang lain, asalkan isi dan adegan film sesuai dengan materi pelajaran.

3. Respon Peserta Didik terhadap pembelajaran SKI dengan penggunaan media film tersebut di MTsN Model Padang

Berdasarkan wawancara penulis dengan salah seorang peserta didik, ia mengatakan bahwa pembelajaran SKI dengan menggunakan media film sangat menarik, sehingga belajar terasa menyenangkan. Pendapat lain juga diungkapkan oleh seorang peserta didik, ia mengatakan 
bahwa pembelajaran SKI dengan menggunakan media film menimbulkan kesenangan tersendiri dalam belajar, sehingga ia merasa rugi kalau ia tidak ikut belajar. Peserta didik lain juga menyampaikan pendapatnya tentang pembelajaran SKI dengan menggunakan media film, ia mengatakan bahwa menonton film dalam belajar adalah suatu yang baru, sehingga ia sangat bersemangat dalam belajar.

Berdasarkan wawancara penulis dengan guru SKI, beliau mengatakan bahwa pada saat pembelajaran berlangsung, peserta didik memperhatikan film dengan fokus. Tidak satupun dari peserta didik yang meribut, sehingga keadaan lokal terkendali dengan baik. Lebih lanjut guru SKI mengatakan bahwa peserta didik sangat antusias untuk memonton film. Terbukti ketika suatu kelas belum dapat giliran belajar dengan menggunakan media film, peserta didik kelas tersebut bertanya-tanya kapan giliran mereka. Begitu juga setelah peserta didik mengikuti pelajaran SKI dengan menggunakan media film, mereka pun bertanya kepada gurunya kapan belajar seperti ini lagi. Dari beberapa pendapat di atas jelas bahwa pembelajaran SKI dengan menggunakan media film sangat menarik bagi peserta didik sehingga mereka termotivasi untuk belajar.

Berdasarkan wawancara penulis dengan peserta didik, mereka mengatakan bahwa belajar SKI dengan mempergunakan media film, membuat mereka mudah memahami pelajaran dan mengingatnya,sehingga ketika guru bertanya kepada mereka atau dalam ulangan harian atau ujian akhir semester, mereka dapat menjawab pertanyaan dengan mudah.

Hasil wawancara penulis dengan guru dan peserta didik di atas dapat disimpulkan bahwa penggunaan media film dalam pembelajaran SKI di MTsN Model Padang memberi kesan positif bagi peserta didik dan mereka termotivasi dalam belajar, sehingga keadaan kelas terkelola dengan baik. Di samping itu, peserta didik juga dapat memahami dan mengingat pelajaran dengan mudah sehingga hasil belajar peserta didik sangat baik.

\section{Simpulan}

Berdasarkan hasil penelitian yang penulis kemukakan, maka dapat diambil kesimpulan sebagai berikut:

1. Teknik pemanfaatan film oleh guru dalam pembelajaran SKI di MTsN Model Padang sudah baik. Berdasarkan hasil wawancara, bahwa guru SKI telah menguasai langkah- 
langkah penggunaan media film. Berdasarkan hasil observasi bahwa guru SKI menggunakan strategi yang tepat dalam pembelajaran.

2. Media film dalam pembelajaran SKI di MTsN Model Padang hanya dapat digunakan pada SK dan KD tertentu saja. Berdasarkan hasil wawancara dijelaskan bahwa media film digunakan hanya untuk menjelaskan materi tentang perjalanan dakwah Rasulullah di Mekah dan Madinah. Berdasarkan hasil observasi bahwa film The Message sebagai media pembelajaran SKI sudah tepat dari segi isi, namun butuh penjelasan dari guru pada adegan-adegan tertentu dan tokoh-tokohnya.

3. Respon peserta didik terhadap pemanfaatan film sebagai media pembelajaran SKI di kelas VII MTsN Model Padang sangat baik. Dari hasil wawancara bahwa penggunaan media film dalam pembelajaran SKI memberikan kesan positif bagi peserta didik dan mereka termotivasi dalam dalam belajar. Di samping itu, secara umum peserta didik menguasai materi pembelajaran yang disampaikan dengan media film.

Berdasarkan hasil penelitian, maka penulis memberikan rekomendasi sebagai berikut:

1. Kepada guru mata pelajaran SKI diharapkan agar dapat mempertahankan pemanfaatan film sebagai media pembelajaran, selalu berusaha mencari ide dan inovasi dalam melaksanakan kegiatan pembelajaran, meningkatkan kerjasama dengan seluruh komponen yang ada di sekolah untuk menyempurnakan pemanfaatan film sebagai media pembelajaran.

2. Kepada guru bidang agama Islam lainnya agar juga dapat memanfaatkan media film sebagai media pelajaran karena media film tidak hanya cocok untuk mata pelajaran SKI saja.

3. Kepada pihak madrasah diharapkan agar terus memberikan dukungan kepada guru mata pelajaran SKI dalam pemanfaatan film sebagai media pembelajaran

4. Kepada pihak madrasah diharapkan untuk dapat meningkatkan fasilitas mengajar yang diperlukan oleh guru dalam melaksanakan pembelajaran di kelas agar proses pembelajaran akan menjadi menarik dan meningkatkan minat peserta didik.

\section{DAFTAR PUSTAKA}

Arsyad, Azhar. 2003. Media Pembelajaran. Jakarta: PT RajaGrafindo Persada.

Djamarah, Syaiful Bahri dkk. 2006. Stategi Belajar Mengajar. Jakarta: PT Rineka Cipta. Hamalik, Oemar. 1989. Media Pendidikan. Bandung: PT. Citra Aditya Bakti. 
Harjanto. 2006. Perencanaan Pengajaran. Jakarta: Rineka Cipta.

Latuheru, John D. 1988. Media Pembelajaran. Jakarta: Depdikbud.

Permenag 2008. BAB VII Standar Kompetensi (SK) dan Kompetensi Dasar (KD) Mata Pelajaran Pendidikan Agama Islam Dan Bahasa Arab Madrasah Tsanawiyah.

Sadiman, Arief S. dkk. 2007. Media Pendidikan : Pengertian, Pengembangan dan Pemanfaatan. Jakarta: PT. RajaGrafindo Persada.

Sarwat, Ahmad. Dasar Keharaman Menggambar Wajah Muhammad SAW. http://islam.dagdigdug.com/dasar-keharaman-menggambar-wajah-nabimuhammad-saw/

Sudjana, Nana dkk. 1990. Media Pengajaran. Bandung: CV Sinar Baru.

Sugiyono. 2008 . Metode Penelitian Pendidikan Pendekatan Kuantitatif, Kualitatif, dan RSD. Bandung : CV Alfabeta. cet Ke- 6.

Supriatna, Dadang. 2009. Pengenalan Media Pembelajaran-Bahan ajar untuk Diklat E-Training PPPPTK TK dan PLB. pdf.

Suryabrata, Sumadi. 2006. Metodologi Penelitian. Jakarta: PT. Rajagrafindo Persada Usman, M. Basyiruddin dan Asnawir. 2002. Media Pembelajaran. Jakarta: Ciputat Pers

Wijaya, Endiarto. Film Indonesia dan Pembelajaran Sejarah http://sosbud.kompasiana.com/2009/12/19/film-indonesia-dan-pembelajaransejarah/

Yamin, Martinis. 2008. Desain Pembelajaran Berbasis Tingkat Satuan Pendidikan. Jakarta: Gaung Persada Press 